J. Perinat. Med. 15 (1987) 31

\title{
The role of phosphatidylglycerol in phospholipid analysis of tracheal and gastric aspirate in premature infants
}

\author{
Eberhard Schmidt-Sommerfeld, Wolfgang Kattner, and Duna Penn
}

Department of Pediatric, Justus-Liebig-University, Giessen, Fed. Rep. Germany

\section{Introduction}

Phospholipid analyses in tracheal, hypopharyngeal or gastric aspirates of premature infants have been performed in order to predict or to establish the diagnosis of hyaline membrane disease (HMD) $[1,2,3,4,7]$. The predictive value of solely measuring the lecithin/spingomyelin ratio $(\mathrm{L} / \mathrm{S})$ in these fluids is controversial. Few studies have included the detection of phosphatidylglycerol (PG), a very specific minor phospholipid of pulmonary surfactant $[5$, 11]. No information is available as to whether tracheal and gastric aspirates at birth have a different phospholipid composition and thereby a different predictive value.

We analyzed simultaneously sampled tracheal and gastric aspirates from premature infants shortly after birth in order to compare these 2 aspirates and to determine whether the inclusion of PG in the analysis improves the predictive value of the $\mathrm{L} / \mathrm{S}$ ratio.

\section{Patients and methods}

Fifty-eight premature infants 27 to 37 weeks of gestation (mean 32.5) with a birth weight ranging between 780 and $3260 \mathrm{~g}$ (mean $1760 \mathrm{~g}$ ) and 10 healthy term control infants were included in the study. HMD was diagnosed in 30 premature infants who required more than 48 hours of respiratory assistance (ventilation or CPAP) and exhibited a characteristic clinical course and chest $\mathrm{x}$-ray (reticulogranular pattern with air bronchograms). Of the remaining 28 premature infants, 22 had adaptational respiratory problems. They needed respiratory assistance for less than 48 hours and had a chest $\mathrm{x}$-ray which was either normal or characteristic for wet lung (central streaking). 6 premature infants had no respiratory problems and a normal chest $x$-ray. Infants with proven or strongly suspected infection and infants with congenital heart disease were excluded from the study. The term control infants were clinically normal. Since intubation was not indicated, only gastic aspirates were collected at birth from these infants.

Gastric aspirates were collected in the delivery room immediately after birth during routine suctioning using a trap between catheter and pump. These aspirates also contained esophageal and hypopharyngeal secretions. Tracheal aspirates were taken shortly thereafter when the infants had been intubated for resuscitation or secure transport to the newborn ICU. They were collected after instillation of $1 \mathrm{ml}$ physiological saline into the tracheal tube and bagging. Suction tubing was rinsed with $1 \mathrm{ml}$ physiological saline and the wash was added to the aspirate. This procedure was repeated once or twice and the samples were pooled for analysis. The maximal time span between birth and last tracheal suctioning was 6 hours. 
In 22 premature infants, only tracheal aspirate; in 11 , only gastric aspirate; and in 25 , both aspirates could be analyzed and evaluated. This was due to either insufficient or excessive phospholipid content of the sample which made an adequate chromatographic separation or densitometric evaluation impossible.

The samples were stored at $-20^{\circ} \mathrm{C}$ until analysis. For analysis they were supplemented with physiological saline up to a volume of $3 \mathrm{ml}$ and extracted with $9 \mathrm{ml}$ chloroform-methanol $2: 1$ $(\mathrm{v} / \mathrm{v})$ without prior centrifugation. The lipid extract was precipitated with $1 \mathrm{ml}$ cold acetone [9]. The phospholipids were separated by 2dimensional TLC using the method of KuLOVICH et al. [9] with 2 modifications [12]: (1) precoated silica gel plates* were used; (2) the spots were visualized with a spray containing phosphomolybdic acid [13]. For comparative measurements $50 \mu \mathrm{g}$ of a standard mixture of lecithin and sphingomyelin $2: 1(\mathrm{w} / \mathrm{w})$ were also applied to the plate. Phospholipids were quantified using reflectance densitometry (Farrand Vis-UV-2-Chromatogram Analyzer). The measurements were accepted for evaluation only if the amount of total phospholipids on the plate exceeded $50 \mu \mathrm{g}$ as determined by comparison with the weighed L/S standard.

The sensitivity of phospholipid detection was $0.5 \mu \mathrm{g}$. The concentration of PG was expressed as \% of total phospholipids. PG was called

* Kieselgel 60, Merck "mature" if its concentration was $\geq 1 \%$ and "immature" if it was $<1 \%$. The densitometric $\mathrm{L} / \mathrm{S}$ ratio of the sample was related to that of the weighed standard in order to correct for inter-run differences in staining.

\section{Results}

The L/S values and the concentrations of PG were higher in tracheal compared with gastric aspirates. The $\mathrm{L} / \mathrm{S}$ ratio was higher in infants without HMD than in infants with HMD (table I).

The cutoff point of the $\mathrm{L} / \mathrm{S}$ ratio separating "mature" from "immature" was chosen so that the number of correctly predicted cases (HMD + no HMD) was highest. According to our data, it was 3.5 for tracheal aspirate and 2.0 for gastric aspirate (figures 1 and 2).

The predictive values of $\mathrm{L} / \mathrm{S}$ were defined as the percent of "immature" (or "mature") L/S ratios which were associated with HMD (or its absence) related to the total number of "immature" (or "mature") L/S ratios. The predictive values of $\mathrm{PG}$ and combined $\mathrm{L} / \mathrm{S}$ and $\mathrm{PG}$ were analogously defined. In both aspirates, the predictive value of an "immature" L/S ratio was higher than that of "immature" PG and was not improved by PG determination. However, the predictive value of a "mature" $\mathrm{L} / \mathrm{S}$ ratio was considerably enhanced by PG determination (table II).

Table I. L/S ratio and PG concentrations (in \% of total phospholipids) in tracheal and gastric aspirates of premature infants with and without HMD (mean \pm SD).

\begin{tabular}{lclll}
\hline & (n) & Tracheal aspirate & Gastric aspirate & Tracheal vs. Gastric* \\
\hline L/S ratio & & & & \\
HMD & 10 & $4.0 \pm 3.8$ & $1.8 \pm 0.8$ & $\mathrm{p}<0.05$ \\
no HMD & 10 & $9.5 \pm 4.9$ & $3.7 \pm 2.2$ & $\mathrm{p}<0.01$ \\
HMD vs. no HMD & & $\mathrm{p}<0.001$ & \\
PG (\%) & & & & $\mathrm{p}<0.01$ \\
no HMD & 13 & $8.8 \pm 4.2$ & $3.0 \pm 2.9$ & \\
\hline
\end{tabular}

Wilcoxon signed rank test for related $\left(^{*}\right)$ and unrelated $(* *)$ samples

a infants with $\mathrm{L} / \mathrm{S}$ ratio $>20(\mathrm{n}=5)$ not included 


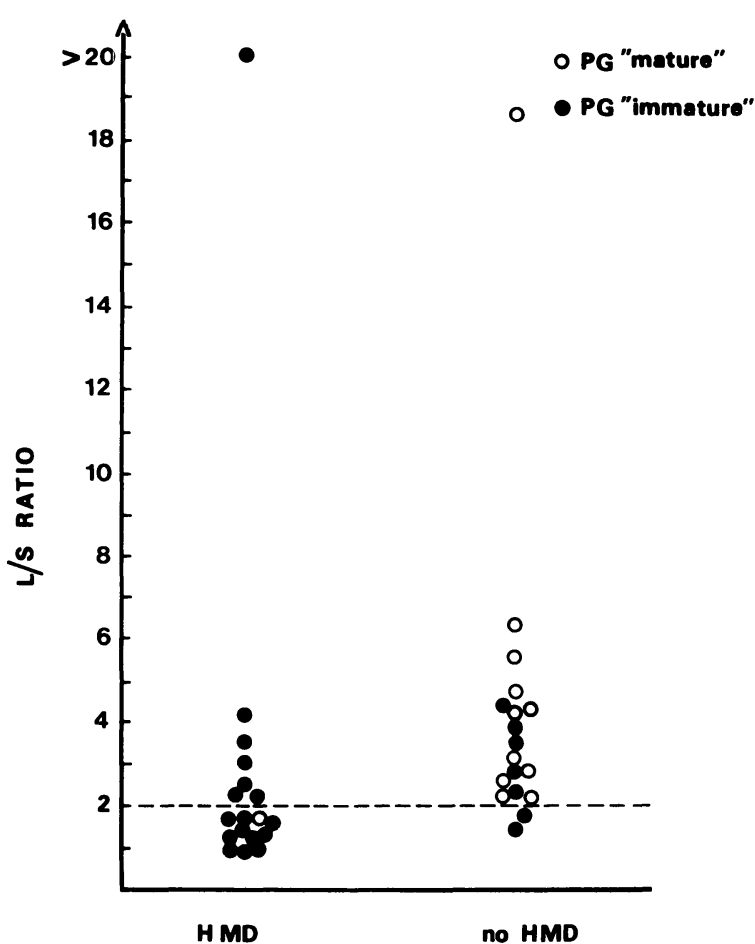

Figure 1. Gastric aspirate phospholipids in premature infants with and without hyaline membrane disease (HMD). The open circles represent "mature", the closed circles "immature" phosphatidylglycerol (PG). The L/S ratio is given at the ordinate. The dotted line represents the cutoff point of the L/S ratio.

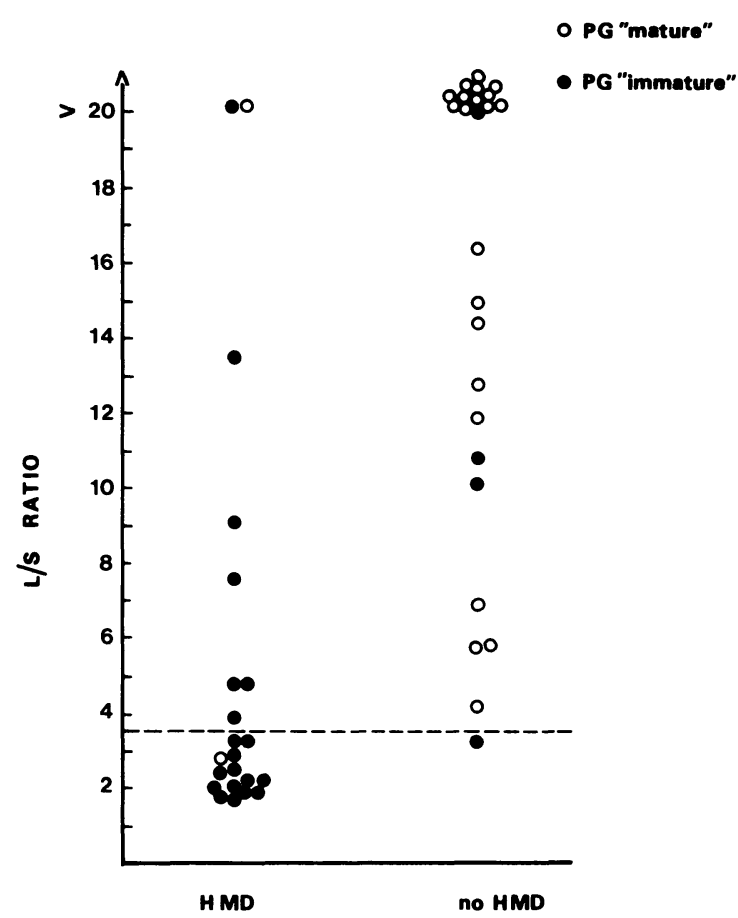

Figure 2. Tracheal aspirate phospholipids in premature infants with and without hyaline membrane disease (HMD). The open circles represent "mature", the closed circles "immature" phosphatidylglycerol (PG). The L/S ratio is given at the ordinate. The dotted line represents the cutoff point of the $\mathrm{L} / \mathrm{S}$ ratio.

Table II. Predictive values (in \%: for definition, see text) of the L/S ratio, PG or the combination of both in tracheal $(n=47)$ and/or gastric $(n=36)$ aspirates. The numbers of samples are given in parentheses.

\begin{tabular}{|c|c|c|c|c|c|c|}
\hline & \multicolumn{3}{|c|}{ Tracheal aspirate } & \multicolumn{3}{|c|}{ Gastric aspirate } \\
\hline & $\mathrm{L} / \mathrm{S}$ & PG & $\mathrm{L} / \mathrm{S}+\mathrm{PG}$ & $\mathrm{L} / \mathrm{S}$ & PG & $\mathrm{L} / \mathrm{S}+\mathrm{PG}$ \\
\hline "Mature" & $\begin{array}{l}75 \% \\
(24)\end{array}$ & $\begin{array}{l}91 \% \\
(21)\end{array}$ & $\begin{array}{l}95 \% \\
(21)\end{array}$ & $\begin{array}{l}70 \% \\
(16)\end{array}$ & $\begin{array}{l}92 \% \\
(11)\end{array}$ & $\begin{array}{l}100 \% \\
(11)\end{array}$ \\
\hline "Immature" & $\begin{array}{l}93 \% \\
(14)\end{array}$ & $\begin{array}{l}83 \% \\
(20)\end{array}$ & $\begin{array}{l}93 \% \\
(13)\end{array}$ & $\begin{array}{l}85 \% \\
(11)\end{array}$ & $\begin{array}{l}71 \% \\
(17)\end{array}$ & $\begin{array}{l}83 \% \\
(10)\end{array}$ \\
\hline
\end{tabular}

Only one out of 22 infants with HMD had a completely "mature" phospholipid profile in its tracheal aspirate. Following prenatal administration of corticosteroids, the infant was born after 28 weeks of gestation, weighed $890 \mathrm{~g}$, and developed a slowly progressing HMD complicated by a symptomatic patent ductus arteriosus.
Two vaginally delivered premature infants had an "immature" phospholipid pattern in their gastric aspirates, but a "mature" one in their tracheal aspirates. One of them required no, the other only transitional respiratory support. Both infants had a normal chest x-ray.

All full term control infants had "mature" phospholipid profiles in their gastric aspirates. 


\section{Discussion}

The results indicate that phospholipid analysis of tracheal and gastric aspirates shortly after birth is useful in the biochemical diagnosis of HMD. However, considering that gastric content at birth mainly consists of amniotic fluid, i. e. prenatally secreted surfactant [3], and that tracheal fluid more closely resembles lung effluent at the time of sampling, i. e. after the stress of birth and resuscitation, it is not surprising that the concentrations of surface active phospholipids are higher in tracheal compared with gastric aspirate. Therefore, different cutoff points for the L/S ratio have to be used to predict lung maturity. These are not only dependent on the nature of the secretion, but also on the time interval between birth and sampling and on the analytical methods used.

From our data, the occurrence of HMD is better predicted by the $\mathrm{L} / \mathrm{S}$ ratio than by PG. However, for the prediction of the non-occurrence of HMD, the opposite is true. A combination of both parameters improves the pre- viously reported [8] high rate of "false mature" $\mathrm{L} / \mathrm{S}$ ratios, but not the rate of "false immature" $\mathrm{L} / \mathrm{S}$ ratios.

Our study also demonstrates that a mature phospholipid profile does not always exclude the occurrence of HMD. This has been previously described, especially in very low birth weight infants, and has been attributed to some as yet unknown surfactant inhibiting protein [6].

On the other hand, false predictions of HMD may occur, especially if only gastric aspirate is analyzed. These may be avoided by simultaneous tracheal aspirate analysis. A comparison of the two may give insight into the dynamics of perinatal surfactant secretion.

Phospholipid analysis in aspirates is time-consuming and therefore of limited value for routine use. However, its clinical relevance may increase if more rapid, e. g. enzymatic methods, become available [10]. It may prove to be important in establishing criteria for a therapeutic trial of surfactant substitution.

\section{Summary}

Tracheal and gastric aspirates from premature infants simultaneously sampled shortly after birth were analyzed for their phospholipid composition using 2-dimensional thin layer chromatography. The results were related to clinical outcome. The L/S ratio was higher in infants without than in infants with hyaline membrane disease (HMD). The L/S values and the concentrations of phosphatidylglycerol (PG) were higher in tracheal compared with gastric aspirates (table I). This resulted in different $\mathrm{L} / \mathrm{S}$ cutoff points with respect to lung maturity. In both aspirates, the predictive value of a "mature" (but not of an "immature") L/S ratio was improved by PG determination (table II). Only one out of 22 infants with HMD had a completely "mature" phospholipid profile in its tracheal aspirate. Two vaginally delivered premature infants without HMD had an "immature" phospholipid pattern in their gactric aspirates, but a "mature" one in their tracheal aspirates.

The results indicate that phospholipid analysis of tracheal and gastric aspirates shortly after birth is useful in the biochemical diagnosis of HMD if proper cutoff points for the $\mathrm{L} / \mathrm{S}$ ratio are used and the determination of PG is included. It may prove to be important in establishing criteria for a therapeutic trial of surfactant substitution.

Keywords: Gastric aspirate, hyaline membrane disease, L/S ratio, lung maturity, phosphatidylglycerol, premature infants, surfactant, tracheal aspirate.

\section{Zusammenfassung}

Die Rolle des Phosphatidylglycerols bei der Analyse von Phospholipiden des Tracheal- und Magensekrets von Frühgeborenen

Trachealsekrete und Mageninhalt von Frühgeborenen wurden kurz nach der Geburt gleichzeitig gewonnen und ihre Phospholipidzusammensetzung mittels zweidimen- sionaler Dünnschichtchromatographie analysiert. Die Ergebnisse wurden mit dem klinischen Verlauf korreliert. Der L/S-Quotient war bei Kindern ohne Hyaline-Membranen-Krankheit (HMK) höher als bei solchen mit HMK. Die L/S-Werte und die Konzentrationen von Phosphatidylglycerol (PG) waren im Trachealsekret hö- 
her als im Mageninhalt (Tabelle I). Dies resultierte in unterschiedlichen L/S-Grenzwerten zwischen reifer und unreifer Lunge. In beiden Sekreten wurde der Vorhersagewert eines „reifen“ (nicht jedoch eines „unreifen“) L/ S-Quotienten durch die Bestimmung des PG verbessert (Tabelle II). Nur eines von 22 Frühgeborenen mit HMK hatte ein vollkommen „reifes“ Phospholipidmuster im Trachealsekret. Zwei vaginal entbundene Frühgeborene ohne HMK hatten im Mageninhalt ein „unreifes“, im
Trachealsekret hingegen ein „reifes“ Phospholipidmuster.

Die Ergebnisse zeigen, daß die Phospholipidanalyse des Trachealsekrets und des Mageninhalts kurz nach der Geburt als biochemischer Parameter für die Diagnose der HMK brauchbar ist, vorausgesetzt, die richtigen L/S-Grenzwerte werden zugrundegelegt und PG wird mitbestimmt. Eine solche Analyse könnte wichtig werden, wenn Kriterien für den therapeutischen Einsatz von Surfactant aufzustellen sind.

Schlüsselwörter: Frühgeborene, Hyaline-Membranen-Krankheit, L/S Ratio, Lungenreife, Magensekret, Phosphatidylglcerol, Surfactant, Trachealsekret.

\section{Résumé}

Rôle du phosphatidylglycerol dans l'analyse des phospholipides des liquides d'aspiration trachéale et gastrique chez les prématurés

On a analysé la composition phospholipidique, par chromatographie en couche mince à 2 dimensions, des liquides d'aspiration trachéale et gastrique prélevés simultanément peu de temps après la naissance chez des prématurés. Les résultats ont été corrélés à l'évolution clinique. Le rapport $\mathrm{L} / \mathrm{S}$ est plus élevé chez les enfants sans maladie des membranes hyalines (MMH) que chez les enfants atteints. Les valeurs du rapport $L / S$ et les concentrations de phosphatidylglycerol (PG) sont plus élevées dans les liquides trachéaux que dans les liquides gastriques (tableau I). Cela entraîne des niveaux de rapports $\mathrm{L} / \mathrm{S}$ différents mais respectant la maturité pulmonaire. La valeur prédictive d'un rapport $\mathrm{L} / \mathrm{S}$ «mature» (ce n'est pas vrai pour les rapports «immatures») est confirmé par la détermination du PG dans les deux liquides d'aspiration (tableau II). Il n'y a qu'un enfant sur les 22 atteints de $\mathrm{MMH}$ qui ait présenté un profil phospholipidique bien «mature» dans son liquide d'aspiration trachéale. Deux enfants prématurés nés par voie basse sans $\mathrm{MMH}$ ont présenté un profil phospholipidique «immature» dans leurs liquides d'aspiration gastrique, mais avec un profil «mature» dans leurs liquides trachéaux.

Ces résultats indiquent que l'analyse des phospholipides des liquides d'aspiration trachéale et gastrique, peu de temps après la naissance, est utile pour le diagnostic biochimique de $\mathrm{MMH}$ si l'on se sert des valeurs appropriées du rapport $\mathrm{L} / \mathrm{S}$ et à condition d'inclure la détermination du PG. Cette analyse peut être essayée comme critère important pour un essai thérapeutique de substitution de surfactant.

Mots-clés: Liquide d'aspiration gastrique, liquide d'aspiration trachéal, maladie des maturité pulmonaire, prématurés, membranes hyalines, rapport $\mathrm{L} / \mathrm{S}$, surfactant.

Acknowledgements: We thank the nurses of Station Bessau and the newborn transport team for their help in the collection of aspirates.

\section{References}

[1] Armstrong D, DE van Wormer, WP Gideon: Predicting respiratory distress by thin-layer chromatography of the newborn gastric aspirate. Obstet Gynecol 48 (1976) 35

[2] BARR PA, PA OENKINS, JD BAUM: Lecithin/ sphingomyelin ratio in hypopharyngeal aspirate of newborn infants. Arch Dis Child 50 (1975) 856

[3] Biggs JSG, J Hemming, H McGeary, TJ GaffNey: Human amniotic and fetal neonatal pharyngeal fluids. Am J Obstet Gynecol 81 (1974) 70

[4] BlumenFeld IA, JM DRISCOLl, LS JAMES: Lecithin/ sphingomyelin ratios in tracheal and pharyngeal aspirates in respiratory distress syndrome. J Pediatr 85 (1974) 403
[5] Hallman M, BH Feldman, E Kirkpatrick, L GLUCK: Absence of phosphatidylglycerol (PG) in respiratory distress syndrome in the newborn, Study of the minor surfactant phospholipids in newborns. Pediatr Res 11 (1977) 714

[6] KANKAANPÄÄ M, M Hallman: Respiratory distress syndrome in very low birthweight infants with occasionally normal surfactant phospholipids. Eur J Pediatr 139 (1982) 31

[7] KANTo WP JR, RC BoreR JR, DW RolofF: Postnatal changes in the L/S-ratio of tracheal aspirates from infants with severe respiratory distress syndrome. J Pediatr 84 (1974) 921 
[8] KoR VENRANTA H: Gastric aspirate lecithin/sphingomyelin ratio and neonatal breathing difficulties. Gynecol Obstet Invest 15 (1983) 177.

[9] Kulovich M, M Hallman, L Gluck: The lung profile: I. Normal pregnancy. Am J Obstet Gynecol 135 (1979) 57

[10] Muneshige A, T OKazaKi, JG Quirk, PC McDonALD, M NozaKI, JM Johnston: A rapid and specific enzymatic method for the quantification of phosphatidylcholine, disaturated phosphatidylcholine, and phosphatidylglycerol in amniotic fluid. Am J Obstet Gynecol 145 (1983) 474

[11] OBLADEN M: Factors influencing surfactant composition in the newborn infant. Eur J Pediatr 128 (1978) 129
[12] SChmidt-Sommerfeld E, H LitMeyer, D PeNN: A rapid qualitative method for detecting phosphatidylglycerol in amniotic fluid. Clin Chim Acta 119 (1982) 243

[13] Verhoeven AG, HM Merkus: Procedure for the determination of the lecithinsphingomyelin $(\mathrm{L} / \mathrm{S})$ ratio in amniotic fluid with a new detection reagent. Clin Chim Acta 53 (1974) 229

Received February 12, 1986. Revised March 26, 1986. Accepted April 24, 1986.

Priv. Doz. Dr. E. Schmidt-Sommerfeld Zentrum für Kinderheilkunde Feulgenstr. 12 D-6300 Giessen, Fed. Rep. Germany 